\title{
Institutionalisation of Women's Studies Research Centre, Gauhati University: A Struggle for Space and Identity
}

Dipmala Dutta $^{\dagger}$ and Dr Polly Vauquline ${ }^{{ }^{*}}$

\section{Abstract}

Although the institutionalisation of Women's Studies (WS) in India started in the 1970s, it took a decade further to cross the threshold of Northeastern States. The isolation which the Northeast of India has always faced in the social, economic and political spheres was also reflected in the case of establishment of the Women's Studies Centre as the then Vice Chancellor Dr. Deba Prasad Barooah had to struggle against the University Grants Commission for establishing it in Gauhati University (GU). Again, the narratives of Women's Studies Research Centre (WSRC), GU do not find mention in the book Narratives from Women's Studies Family: Recreating Knowledge where experiences of 17 centres from across the country are illustrated. This article investigates all such structural difficulties, negligence and struggle faced by one of the first Women's Studies Centre of Northeast India, established in Gauhati University, since its conceptualisation to inception in 1989 till the present. It attempts in revealing the experiences of the Directors, yielding the efforts behind the setting up of the centre, the role played by different individuals both internal and external of the University towards the establishment of the Centre, the catalysts that prevented the premature decay of the Centre and most importantly, the struggle for space, identity and recognition of the constraints faced to obtain them. To achieve these goals, oral history method was applied to explore the experiences of the previous directors and the author (2nd author) herself. The narratives illustrate the history of struggles, challenges and the subsequent development over a span of more than 25years. The article documents the support the University provided for fostering of the WSRC, which in gradual years took steps to produce the Department of Women's Studies. It will also look into the progressive role Women's Studies played not only in the university internally but also at the external front through research and advocacy by inducing new panoramic view towards and discussion of women's issues in a multidimensional framework.

Keywords: Institutionalisation, Women's Studies Research Centre (WSRC), Space, Identity, Gauhati University, Northeast India

\footnotetext{
†Independent Researcher, Assam, India, Email: dipmala.dutta@gmail.com

${ }^{*}$ Corresponding Author

'Associate Professor, Department of Women's Studies, Gauhati University, Email: pollyvauquline@gauhati.ac.in (C)2018 Dutta and Vauquline. This is an Open Access article distributed under the terms of the Creative Commons Attribution License (http://creativecommons.org/licenses/by/2.0), which permits unrestricted use, distribution, and reproduction in any medium, provided the original work is properly cited.
} 


\section{Introduction}

Women's Studies (WS) is a scholarly discipline of the academics which indulges in theoretical insights and intellectual inquiry, and has an indispensable and complex relationships with other disciplines (Blee, 2002). The predominant disciplines have androcentric knowledge base and WS intervenes in them with gender analysis to remove the biases they possessed (Hesse-Biber, 2012). It would be worth mentioning that WS created its space and identity by critiquing other disciplines because it is characterised as interdisciplinary and also multidisciplinary but these two features also helped WS to emerge as an individual entity as an established discipline engaging feminist theory (Blee, 2002; Wiegman, 2001).

WS as an institutional site emerged from women's activism, and thus, has an unconventional position as units in colleges and universities (Desai, Mazumdar and Bhansali, 2003; Blee, 2002; Zimmerman, 2002). It ventured into academic arena as not only as a theoretical activity but also to as a research and analytical unit and along with setting up a base for academic establishment (Zimmerman, 2002). Pertinently, during the emergence of WS there was a friction between the WS as an academia and activism. Meanwhile with the structural adjustments, the universities seemed to be more approving of WS and the latter found it as more of academics (Zimmerman, 2002) and it is pertinent in the context of WS, Gauhati University.

The article is about the journey of the institutionalisation of WSRC, GU which is broadly divided into four parts. In the initial part of the article the inception of the centre is discussed through the narratives of the founder Director, Professor Renu Debi. The Centre has almost gone through an extinct phase. That is the second part of the article which is expressed through the narratives of Professor Kunja Medhi. However, it again revived during the tenure of Professor Archana Sharma which is illustrated through the narratives of Professor Sharma. Lastly, the present state of the Centre is voiced through the narratives of
Dr Polly Vauquline. The interviews were conducted from February 2016 to May 2016.

\section{Background}

Women's Studies started in the colleges in the United States of America (USA) by late 1960s and by 1970 s spread through many campuses there (Easton, 1996; Zimmerman, 2002). It could be very well noted that the sphere of women's studies was broadening phenomenally by the 1980s and got institutionalised in North and South America, Australia and New Zealand, Europe and Asia (Richardson, 1997). These establishments of WS and its process of development was opportune because this was the time when research on women was developing through conferences, networks, journals, research centres and publishing houses (Richardson, 1997).

Women's Studies as a discipline arose from feminism rather than from the contentgender and women (Orr, 2012). Thus, the early aggression concerning the endeavour of WS in the universities gradually mellowed down due to the intellectual capacity of the feminist scholarship (Crowley, 1999). In the course of time, women's studies created its own space of secured residence in the universities due to the efforts of the women's and students' movement (Crowley, 1999).

The feminist stalwarts of India, who rose from Indian women's movement, identified the Committee on the Status of Women in India (CSWI) as the watershed report published in 1974, which unveiled the grim reality on the condition of women in the country, which had been brushed under the carpet since independence. The abysmal findings reinforced the women's question to the then Congress government headed by the Former Prime Minister late Mrs Indira Gandhi, academia and women's organisations (Jain \& Rajput, 2003). Therefore, the emergence of Women's Studies in India could not be discussed without mentioning the CSWI Report, popularly known as 'Towards Equality' Report (Desai, Mazumdar \& Bhansali, 2003). But WS as academics formally started in India in flesh and bone when 
the Indian Council of Social Science Research (ICSSR) constituted an Advisory Committee on Women's Studies to understand the issues that affect women (Juyal, 2005, Jain \& Rajput, 2003). ICSSR had defined WS as an academic field which would include research, documentation, training and advocacy; thus, it was important for it to be opened firstly as centres in the academic institutions and form a database for comprehension of the existing misogyny and subordinate status of women in the society and also to engage in discourses on social sciences which were androcentric and male biased (Patel \& Khajuria, 2016, p. 5; Krishnaraj, 2003; Jain \& Rajput, 2003; Desai, Mazumdar \& Bhansali, 2003).

The path-breaking consequence of this was the entry of University Grants Commission (UGC) into this field and its articulation of guidelines for the promotion of Women's Studies, by setting up Women's Studies Centres in various universities in India, which vividly put forth the objectives of the women's movement (Jain \& Rajput, 2003). SNDT Women's University was the ground-breaker in establishing Women's Studies as an academic and action oriented institution as the Research Centre for Women's Studies devoted to research on women's issues (Desai, Mazumdar \& Bhansali, 2003). Apparently, with the penetration of WS in one university it spread to others. Its interdisciplinary nature made it a comfortable zone for scholars and in the meantime, research on women were already taking place among other disciplines too by scholars and academicians (Sharma, 2014).

In Northeast India, WS as a centre was first established in Gauhati University, Assam in the year 1989. This step towards setting up the centre was taken by the then Vice-Chancellor Dr. D.P Baruah and the first Director of the Women's Studies Research Centre (WSRC) was Professor Renu Debi, who was heading the Department of Education at that period. This article would discuss about the journey of WSRC's inception, the near extinct phase of WSRC, ensuing revival as a Department of
Women's Studies and the struggle for the present space.

The next section begins with a rationale of the study, followed by the methodological issues linked to the research. This is followed by discussion of the findings of the research.

\section{Rationale of the Study}

Women's Studies had already documented that women's experiences are varied and diverse (Robbins, 1966-76; Davis, 1981; Crowley, 1999). In a diverse landscape like India women's studies is supposedly to be more diverse (Jain \& Rajput, 2003, p. 18). Thus, it can be said that each women's studies family in India has varied stories and a large number of which has been documented very eloquently in the book 'Narratives from the Women's Studies Family: Recreating Knowledge" by Devaki Jain and Pam Rajput. This book presents a detailed narration of 17 women's studies centres across the country among which there is SNDT University, Calcutta University, Punjab University, Alagappa University, Mysore University, etc.

Towards Equality Report, ${ }^{1}$ which was one of its kind publications, and is still considered as the first step towards the fight for improving women's condition in our country because it revealed a very bleak picture of the condition of women across the nation even after somewhat three decades of independence of India from the British Raj? It can be said that the women's movement got a boost from that point and the women's studies centres came out of that friction between the state and activism. The role of the centres in spreading the awareness about the need of taking up women's issues as an area of study across the universities in the country should also not be overlooked.

The fact which prodded this article was absence of the narrative of WSRC, Gauhati University, which in itself was a watershed institution, being the first, one of its kinds

\footnotetext{
${ }^{1}$ Towards Equality, Report of the Committee on the Status of Women in India, Government of India, Ministry of Education \& Social Welfare, Department of Social Welfare, New Delhi, December 1984
} 
established in Assam among the eight sister states of Northeast India. It is an event which served as a turning point to institutionalisation of WS in the region. Other universities in Northeast India followed the lead of WSRC, Gauhati University. In addition to this, the centre since its inception has been actively involved in advocacy, extension activities, documentation and research on women's lives and issues. Here, we would like to refer to the "neglect theory", which is mostly drawn in favour of the economic backwardness of the NE region, (Raghavan, 2013), but obvious neglect has often been cited in terms of political agenda, media coverage, and also in research by Delhi (as the Centre). Northeast had been regarded as backward and continues to be as backward (Nath and Kumar, 2017; Sachdeva, 2006). ${ }^{2}$ On similar terms, it can be deduced that WSRC, GU too had been overlooked by the mainstream division of women's studies. It can be inferred from the fact that even when a book was compiled with stories with narratives from women's studies centres from across the country, WSRC, GU's story was not taken into consideration.

Thus, more or less after 25 years of establishment of the centre and 7 years of eminence as a department, it is imperative to conduct a narrative study on the first women's studies centre of the region. Within this span of time it has developed itself from a Phase I

\footnotetext{
${ }^{2}$ This is despite a dedicated Ministry of Development of North Eastern Region (MDoNER), which is a ministry of the Government of India, established in September 2001and further transformed into a full-fledged ministry on May 2004. All the eight states of Northeast India are considered as special category states, the development plans being funded by Central Government on the basis of 90 per cent grant and 10 per cent loan. The whole region is mired in insurgency (Verghese, 2013). The Look East Policy, which was launched in the 1990s (now newly renamed as Act East Policy) is yet to showcase the fruits of development (see for details, Nath and Kumar, 2017). The Act East Policy has started gaining visibility through Advantage Assam and Assam Start Up Policy 2017 but only time will speak to what extent development is gained through these initiatives (Assam Start Up Policy, 2017, retrieved on June 2018 from, https://advantageassam.com/assets/front/pdf/Start-upPolicy.pdf)
}

Centre to Phase III Centre during UGC's XIth Plan $^{3}$ and from a WSC to a full-fledged department of the University. ${ }^{4}$ As women's studies aims to remove the invisibility of women and tries to bring women in the centre of knowledge production (Easton, 1996, p. 2; Grosz, 1987), this article documents the journey of invisibility of the Centre to visibility of the Department. It also looks into the role of the Directors who were responsible to spearhead the Centre towards its successful existence and to become a site of not only research, analysis and advocacy but also knowledge production. It investigates the constraints faced by the Centre and the favourable factors in support of institutionalisation of WSRC, GU (as per the consultation of Activity Reports, 1997-2016).

Further, through this study the anecdote of a faction of the diverse women's studies family is highlighted, because it is established that women's voices are varied and each experience count to be valuable for the discipline to encourage and motivate the next generations of academicians, scholars and feminists. This article is the voice of the Women's Studies Research Centre, of Gauhati University, which was not heard before.

\section{Methodology}

Historical approach has been used as an aid in visualising society as a dynamic organism where its structures and functions as steadily grow and subsequently, undergoing changes and transformations (Singh, 2006). This study has been formulated on a historical research approach to understand WSRC and Department of WS, the events, developments and experiences of the past. This study has a perspective approach too-studying the events from past to the present. It looks at the process of evolution of WSRC and WS department deploying qualitative research method as it has been described as a form of method of social inquiry that focuses on the way people

\footnotetext{
${ }^{3}$ UGC's XI Plan Guideline for Development of Women's Studies Centre in Universities and Colleges (2007-2012)

${ }^{4}$ Activity Reports of WSRC, GU was consulted form 1997 to 2016.
} 
interpret and make sense of their experiences and the world in which they live in (Holloway, 1997). It is observed that a key aspect of qualitative research is the idea that meaning is constructed by individuals in their uniqueness as part of a particular context and interactions, and those meanings are in turn reflected in state policy documents and laws (Orlikowski \& Baroudi, 1991). This aspect regarding qualitative research is the key determinant for this study as it attempts to document narrations of each individuals who has been part of the particular context and interactions of the history of the centre and the department.

Oral history method was used to understand and document the history of the centre and department in this study because the difficulties, challenges and windows of opportunities opened to the individuals who had played the crucial role for the institution needed more detailing in the historical narrative of the University. Through this method, the narratives illustrate the first hand experiences, the initiatives taken, the challenges faced, and difficulties encountered by the respondents. The desk review was conducted primarily by analysing the departmental documents such as the newsletters and the activity reports.

For this study, out of six former Directors, four of them were interviewed. They are-Professor Renu Debi (1989-1993), Professor Kunja Medhi (1994-1996), Professor Archana Sharma (19962013) and Dr Polly Vauquline (2014-2017), who is one of the authors of the article). The remaining two were not interviewed as they had very short tenure in the centre.

All the interviews were conducted in Guwahati itself as all them are based in the city. The interviews were conducted in the months of May-June, 2016. These interviews were predominantly unstructured. The interviewers mainly played the role of facilitators during the In-depth Interviews encouraging detailing and explanations. Prior to fixing appointments for interviews, the interviewees were informed about the objectives and purpose of the study.
Their consent was also sought to audio record the interviews. All the interviews were conducted at a place and time convenient to the interviewees. Each interview had taken almost an hour. The interviews were conducted mostly in Assamese. The recorded interviews were translated and transcribed simultaneously by the first author. All the transcriptions were accomplished manually to ensure accuracy. Once the transcripts were ready, those who reported for a copy of their interview's transcription were provided with it for their final approval after which the analysis was done on the basis of the study objectives.

\section{The Findings}

The Department of Women's Studies did not sprout overnight; it has a journey from infanthood to adolescence. It existed earlier as Women' Studies Research Centre, which was established in 1989 during the tenure of the former Vice Chancellor, late (Dr). D.P. Baruah, as per UGC guidelines for promotion of Women's Studies across universities in the country. Therefore, the findings comprise of the narratives of the Directors (from 1989 to July 2016)) of WSRC, GU.

\section{The Inception}

Professor Renu Debi, the first Director of WSRC (1989-1993) was from the Department of Education. She did not have any specific reason for taking up this responsibility. She felt that she should be there and that urge was strong. This impulse may be attributed to her active involvement with the University Grants Commission Visiting Committee for Women's Studies. It can be noted here that during that period of time her husband, Dr. Deba Prasad Barooah, who was the Vice Chancellor of Gauhati University was reluctant to appoint her as the Director of WSRC, GU. She had to convince the then Registrar, Dinesh Baroowa, about her willingness to take up the responsibility. Professor Debi was appointed as the first Director of WSRC, GU after taking opinions and consents from larger forum of GU. According to Professor Debi, Women's Studies, across the nation, came into conceptualisation after the publication of Towards Equality 
Report of 1974 as it was the milestone document regarding the reality check on the status of women in the country which called for a step towards upgrading women's lives, which could be known only through proper knowledge and research. Professor Renu Debi recalled her tenure as a Member of Visiting Committee for Women's Studies, UGC, at that time Phulrenu Guha proposed to organise a national-level seminar in Gauhati University. Thus, in the year 1975, Gauhati University organised a National seminar on "Women's Education as an instrument of Changing Society" which was sponsored by UGC, and according to her that was first step of the University towards Women's Studies. She emphasised on two factors which helped in building WS, firstly, research on women was not an aloof subject for academicians like herself or other professors because she and other colleagues were working on research projects on women's issues at that time, and secondly, she and her colleagues were attending conferences and seminars on women's issues and women's studies across the nation. During her tenure, male and female, senior and young faculties from other departments actively participated in the various programs conducted by WSRC. Senior faculties from science department also got involved. It was because of their active involvement with WSRC during that period, a number of female faculties of $\mathrm{GU}$ have got actively involved with research on women's issues in their later life. It can also be attributed to her charismatic personality and leadership quality.

Even Professor Kunja Medhi, the third Director of WSRC (May 1994-October 1994), who also participated in these events with Professor Renu Debi and Dr. Nandita Sharma (Director, WSRC August 1993-May 1994), seconded the views and facts that these events were the site of learning for them about Women's Studies, as in the earlier times, there was hardly any knowledge about WS. The trio visited some of the major events in the history of women's studies like the Bombay Conference (1980) and Vishakhapatnam Conference (1988). She said that though scholars and academicians were conducting research on women and their issues but WS as a concept was fresh to them. These conferences and seminars were the platform to meet the stalwarts of women's movement. Professor Medhi reported that they got to understand in details about the structure of WS in these sites. Further, Professor Archana Sharma, who was appointed as the fourth Director, also observed that a very lively tradition of research on women's issues existed in Gauhati University since it was established. The Directors as well were writing research articles and attending conferences on women's issues from their parent discipline too. The University as an institute was not indifferent towards major research projects taken up by WSRC. This also facilitated in the documentation of materials on women's studies, for which WSRC, GU can now be considered as the nodal centre of Women's Studies of North East India. Networking with organisations and institutions both at the regional and national level developed during this period. Thus, these factors helped them to build up their understanding of the subject and at the same time assisted them to build, nurture and foster WS as an institution in GU and across Assam.

Former Director, Professor Renu Devi stated that neither WSRC was served on a platter to GU nor she became the director effortlessly. She recalled that UGC breathed fresh air when Madhuri Shah joined the commission, and during that time WS centres got established in the western and southern regions of the country. She quoted:

I thought, why we shouldn't have the Centre here in our University too

At that time, as noted above, Dr. D.P Baruah was the Vice Chancellor and he demanded establishment of a Women's Studies Centre in GU because UGC had plans to establish 28 centres in the Universities across the country. She recalled that when a committee was formed by the UGC, the members vouched for centres in their Universities or neighbouring areas but Gauhati was ignored. D.P Baruah 
retorted that like the Centre (Delhi), UGC too never thinks about the Northeast even though GU was then considered one of the best and oldest Universities of the region under UGC. She credited the dynamic personality of Dr. Baruah which played a major role in convincing the UGC.

"The next hurdle I faced was applying for the post of Director", said Professor Renu Debi, as her passion for women's studies clashed with her being the wife of the Vice Chancellor as he expressed that it would place a wrong impression in the institution. Professor Debi stated:

According the UGC guidelines the VC had the power to nominate the Director of WSRC, but he was determined not to nominate $m e$ ". She further said that, "I received support from all the female teachers and they requested the VC for my directorship. Then a selection committee was organised and all the female teachers from Departments of Political science, Philosophy, Education, Botany and Anthropology voted for me. And that's how I became the Director

She said that during her tenure WSRC organised around 14 seminars. Among those few of them were in collaboration with the Departments of Political Science and Economics. It was to spread the ideas for the need of WS and sensitise the students and teachers regarding WS, because there will not be any success without social awareness. She further narrated that:

Among the activities of the WSRC, creating awareness was one of them and for that we visited villages and conducted meetings comprising both men and women

Professor Debi along with her staff of research officers and junior research fellows paid a visit to a school in Bhawanipur, Mangaldoi and Guwahati's Arya Vidyapeeth. She quoted,

At that time there was hardly any concept formation regarding women's studies. People didn't know about the different form of marginalisation that women were facing. They used to ask us... what does it mean? Limitations of women's education were few issues that were taken up in those meetings. That was the first step. One lakh rupees were given to us as fund by Gauhati University. I didn't get any remuneration for that. The University was sympathetic so they provided some additional funds. The students used to offer voluntary services to the WSRC

Professor Medhi said:

During the initial period one of the main objectives of WSRC's was to work in the grassroots level. And as per UGC Guidelines, we need to initiate for the establishment of Women's Studies Cells in Colleges. And we established Women's Cells in few colleges affiliated under GU. But in most cases WS received lukewarm attitudefrom these external institutions, which is evident from the fact that the WSRC could not open a Cell in Cotton College at that time, whereas the Women's Studies Cell existed in Handique Girls' College. Coincidentally it is a girls' college.

Professor Medhi informed that during the initial period, Women's Studies faced challenges from men too. She narrated:

Men refused to attend our meetings maybe because women were holding the central roles

On the other hand, Professor Renu Debi's experiences were of a different kind. She mentioned:

When WSRC was first established, some of my male colleagues mocked at WSRC by saying that the men too would now want to start a Men's Studies Centre.

\section{The Near Death Phase}

Professor Kunja Medhi, who was the Head of the Department of Political Science, took up the responsibility as the Director in May 1994 after a very short stint by Dr. Nandita Sharma, 
who was just a metaphor as a director. She was the Director for a period of nine months; however, no activity was carried out during her tenure. Professor Medhi recalled:

When I took the reins of WSRC in my hands it was in a bad state. Though small research studies were being conducted but other activities such as awareness and advocacy had almost come to a halt.

She also faced constraints regarding support from the then Vice Chancellor, as she stated that:

He hardly allowed me to speak during meetings

She went on to say that, during that phase WSRC also faced a huge dearth of funds:

As a Director it was my responsibility to uplift the centre and there was no activity happening in the Centre for a very long period of time. So, I decided to organise a seminar. We had only six thousand rupees in the WSRC internal funds and somehow managed to incur thirty thousand rupees more from the UGC funds of the University and organised the seminar. On top of that the University also did not handover the funds received from UGC and it was one of the most difficult periods of WSRC

When enquired about help from other sources she recalled and stated:

During my tenure, I received help from other Departments and especially from the colleagues of my own Department

\section{Revival}

The next Director, Professor Archana Sharma (November 1996-2013), who was also the longest serving director of WSRC, reported that she was called upon by the then Vice Chancellor, Professor Hiralal Duara and was asked to take charge of WSRC. Initially, she tried to dissuade him but he did not relent and asked her to join.

She said:
When I joined, the University authority and UGC wanted a consistent Director. It was so because the IX Plan Guidelines demanded more activities on the part of WSRC. It required an able hand for guidance towards fulfilment. Coincidentally the report on Status of Women and Social Change was published and UGC released the funds. Eventually, with the success of other activities WSRC staggered and stood on its feet again.

Professor Sharma further explained:

Though WSRC was developing, all incidents did not happen in true spirits of Women's Studies.

In this regard one of the main difficulties that WSRC was struggling with since its inception was to achieve state government concurrence for its designated posts. When Professor Sharma joined she even met and briefed the Chief Minister in this regard. But it was declined. Subsequently, when the state government regularised the posts, they named the posts as Scientific Officer, Laboratory Assistant, etc. According to Professor Sharma:

Such languages were alien to WS. The state government did not grant the posts as prescribed by the UGC and the centre. But fortunately, those posts were filled in by hard working people. They are the ones who are the main builders of the institution.

The Centre acted on the go with this team headed by Prof Sharma. Seminars, conferences were organised. In addition to the research reports in monograph form, books were also published. She said:

In 1999, the centre started a course on Research Methodology in Gender Studies which became very popular and by the year 2000, M.Phil programme was started which was a need to train human resource in Feminist Theory. With the help of the staffs, WSRC started networking with other Women's Studies Centres, NGOs and 
organisations, which work on gender related issues. The other Departments of the University also joined hands with the Centre. They also revised their curriculum with gender perspective.

She hailed the UGC IX plan which gave immense space for the centre to develop and institutionalise.

Again during the $X$ plan, WS faced another challenge from the previous BJP government which wanted to change the name of Women's Studies to Family Studies and it led to nationwide signature campaign against it under the leadership of women's rights activists like Yashodhara Bagchi. She informed that teaching in Women's Studies was introduced with XI plan guidelines of UGC, and the Standing Committee prescribed to focus mostly on teaching.

When enquired about the challenges she faced, Professor Sharma narrated:

There was always lack of adequate staffs to carry out the activities of the Centre. Another was inconsistency. The Centre did not have permanent status. The fear of its existence was always dependent on every new five year plan. Due to this temporary status and irregular funds, the Centre could not pay salary regularly to its staffs.

\section{The Struggle for Space}

Professor Sharma emphasised that the present space where the WSRC resides was allocated after much written intervention with the University authority. During Professor Renu Debi's tenure, the first set up for WSRC was in a room located in the ground floor of the Old Academic Building. Later it shifted to the Department of Education when it was newly built. It was reported by the Directors that spatial scarcity in the University was the major issue faced by WSRC since the beginning. However, the Professor Renu Debi denied of any negligence on the part of the University and most of her successors did not deny so. Professor Renu Debi denied of any negligence on the part of the University. However,
Professor Medhi confided that during her tenure she faced financial hardships for functioning the centre properly. Conducting seminars are one of the most vital objective and functions of a women's studies centre but she did not receive financial support from the university. The grants from the UGC did not come directly to the centre and the university refused to give the allocated grant to the centre. She revealed that she collected donations from her colleagues to conduct a seminar successfully during her tenure. Interestingly, Professor Sharma pointed out that the fate of WSRC used to change from positive to negative on the whims and fancies of the Vice Chancellor who used to be in office at that time

When WSRC was upgraded to a Department and introduced MA in Women's Studies, there was no class rooms provided to held their classes. As elaborated by Professor Sharma and Dr. Vauquline (the second author), the classes were conducted in various places around the University. It was held in one of the vacant classrooms of the Department of Hindi, the library of the Department of Economics and in unoccupied rooms - in different places of the University. There by, the faculties and the students used to move around from one place to another throughout the day. The authors note that the faculties even had to share one table. Finally, in February 2013, the Department of Women's Studies was provided a space of its own in one of the wings of the New Academic Building. However, again this wing was shared with Sociology. Dr. Vauquline provided the reasoning behind this sharing:

The University told us that since both the departments were new and there were less staffs we should share the wing between the newly formed Departments. Now we had a space of ours but no furniture. Later on we got the achievers for the classes, and then the white boards, markers and the rest followed subsequently 


\section{The Present}

Dr. Polly Vauquline, Director in Charge (20142017), became the Head of the Department of Women's Studies, Department of Women's Studies, in the year 2013 and at that time Dr. Aparna Bhattacharya was appointed as the new Director (2013-2014). According to the second author, WSRC and DWS (since its inception to 2014) existed as two different identities. Later, while going through UGC XI Plan Guideline, it was found that the Centre and the Department could not exist as two different entities and therefore had to merge. So the former Vice Chancellor, Professor Akhil Medhi called upon both the Head and the Director and advised them to merge both the entities, she said. Further she explained:

A committee was formed with senior faculties who were closely associated with WSRC. After a number of sittings and threadbare discussion, it was proposed to merge the two bodies as per the guidelines and a resolution was taken to change the nomenclature from Women's Studies Research Centre to Department of Women's Studies. However, UGC would refer to us as Centre but to other universities and organisations it is a Department

Though there seemed existence of upheavals faced by the Centre, the university always somehow aided the centre for its survival, said all the Directors. It was observed in the study that Women's Studies as an institution was always welcomed into the university since the beginning. The National Assessment and Accreditation Council's (NAAC)'s $s^{5}$ recommendation for some innovative courses in an academic institution was considered as a favourable factor and WS falls under the category of innovative courses. It can be considered as an enhancement together with the adequate funds received from the UGC after it was recognised as third phase centre. At the same time, introduction of interdisciplinary

\footnotetext{
${ }^{5}$ The National Assessment and Accreditation Council (NAAC) is an organisation that assesses and accredits higher education Institutions (HEIs) in India
}

subjects was encouraged as it was also a necessity, and thereby, the demand for WS.

The formation of the department was very crucial for WS to get into the mainstream because as a Centre though it was conducting many activities but those were accomplished in isolation, not as a Department, which has more visibility in a university setup. It is pertinent to note that when it became a Department, the Head could attend meetings involving the Departments of the University. But this scope narrowed down for the Director of WSRC. Dr.Vauquline felt that when it started functioning as a Department it automatically became a part of the University system through its affiliation with the other axillary committees of the University. Thus, the institutionalisation of WSRC through becoming a Department brought more visibility to WS.

Dr. Vauquline mentioned that there is still lack of staff and smooth flow of funds. She emphasised that the funds were irregular because the UGC releases funds on the basis of the submission of the activity reports, thus, sometimes there is a huge gap of time in receiving funds which created problem. She mentioned:

The students were the force the Department banks upon. They help out during the activities through their active involvement and these events also prepare them for future endeavours."

She further said:

Our Department has produced three batches of Masters' students successfully and in future we want to be an Advance Centre

\section{Discussion}

Though WSRC became institutionalised through its promotion into a Department, but the centre was important to prepare a base for the institution by collecting information on women through research and advocacy. The positionality of the Directors was not fixed as they were not appointed as full-fledged Director. They were Honorary Directors and 
operated from different Departments until in July, 2000 when the Centre was provided a space of its own. They acted as crucial agents of change through their location within the power relations between the UGC, University and the Centre (Kezar \& Lester 2010). Moreover, the subject was intriguing for both the authors, firstly, as an educator in this field and secondly, as a student of WS. Hence, we argue that our positions to study the institutionalisation of WSRC would yield better results than any outsider (Allies, 1999).

It could also be argued that this long standing battle of WS in getting institutionalised can be explained through the intersectional attributes of the categories involved in it, that is, women. As per the UGC Guidelines the Director of all Women's Studies Centre should be necessarily a female academician. As women do not have a single or fixed identity and possess intersectional identities (Hesse-Biber, 2012), it allows them to have subjective knowledge and in this regard, each Director poured out their knowledge and led the way of WSRC to where it is standing today.

As pointed by the author, Dr. Vauquline that DWS is enumerated almost at the end of all the Departments because of the alphabet ' $W$ '. It also faces discrimination in hegemonic patriarchal institutions because the subject has entitlement to justice and equality which goes against the culture and ideology of patriarchy (Anderson, 1980; Bhasin, 1993).

Moreover, the main arguments for this article rest on the space, identity and recognition and the struggle behind it. It has been historically established that society had been traditionally divided on the basis of public and private, where men go out in the public and women remain in private (Pateman, 2006; Massey, 2001). However, eventually due to globalisation the line dividing the spheres got blurred and women came out in the public (Rose, 2007). But even though women were accessing the public domain, neither space was redefined for them nor their identity evolved or they received any recognition within that space, thus hardly any power was associated with their position. In case of WSRC it had been documented that the struggle to obtain a permanent space continued for more than a decade at length. Moreover, wherever the meetings of the WS were held male colleagues avoided those areas regarding it as exclusively women's space, clearly show the relationship between space, gender and power (Elden, 2007; Massey, 2001) as traditionally sites of education is dominated by men and with emergence of a space concerning women threatened their hegemonic space occupation being unaware of the thoughts behind the establishment of the centres (Sreerekha, 2016).

It can also be said that the institutionalisation of WSRC received thrust due to the capital attached to it, as NAAC and UGC got involved in it. However, WSRC, GU is not eligible to avail UGC Special Assistance Program (SAP) as it does not fulfil certain criteria. Thus, the capitalist agenda could not be forbidden in this case as the structural adjustments in the country in the 1990s brought the professionalisation into the world women's studies (Roy, 2015).

\section{Conclusion}

This study is an attempt to bring forth the narrative on the first WSRC of Northeast India starting from its inception to withering, revival and upgradation through the use of oral history method. The study documented the events, personalities, situations that the centre has faced so far through the first hand narrations of its leaders.

This documentation of the undocumented evolution of the centre/department reveals the fact that the institutionalised as well as individual initiatives and steps have played a role in creating the Department in its present status. Though this study documents the struggles and challenges faced by the leadership of the Centre/Department from time to time, a 360 degree narrative would be revealed only when an extensive study, based on the principles of the current study, would be conducted among the second line of leadership, other academics, non-academic 
staffs and the former students of the Department.

\section{References}

Allies, L. (1999). Positionality in Life History Research. British Educational Research Association Annual Conference (p. 1). Sheffield: University of Sussex.

Anderson, W. L. (1980). Hegemony and Revolution. London: University of California Press.

Bhasin, K. (1993). What is Patriarchy?

Blee, K. M. (2002). Contending with Disciplinarity. In R. Wiegman, Women's Studies On Its Own (p. 177). London: Duke University.

Crowley, H. (1999). Women's Studies "Between a Rock and a Hard Place or Just Another Cell in the Beehive?". Reviewing Feminisms at Century's End , 137-138.

Davis, A. Y. (1981). Women, Race and Class. USA: Random House.

Desai, N.,Majumder, V. \&Bansali, K. (2003). From women's education to women's studies. In D. J. Rajput, Narratives from the Women's Studies Family: Recreating Knowledge (pp. 52-54). New Delhi: Sage Publications.

Easton, A. (1996). Introduction What is Women's Studies? In A. E. Tess Cosslett, Women Power and Resistance: An Introduction to Women's Studies (pp. 1-2). Open Univesity Press.

Elden, J. W. (2007). Space, Knowledge and Power Foucault and Geography. USA: Ashgate Publishing.

Grosz, E. A.(1987). Feminist Theory and challenge to knowledges, 1987

Hesse-Biber, S. N. (2012). The Handbook of Feminist Research Theory and Praxis Second Edition. Boston: Sage Publications.

Holloway, I. (1997). Basic Concepts for Qualitative Research. Oxford, England: Blackwell Science.
Jain, D., \& Rajput, P. (2003).Introduction. In D. Jain, \& P. Rajput, Narratives from the Women's Studies Family (p. 19). New Delhi: Sage Publications.

Juyal, P. (2005). Women's Studies In India: Some Contemporary Contours. Ehwa Woman's University Press.

Kezar. A. \& Lester, J. (2010). Breaking the Barriers of Essentialism in Leadership Research: Positionality as a Promising Approach. Feminist Formation, 22 (1), 168185.

Krishnaraj, M. (2003). Blazing A Quarter Century Trail. In N. Desai, V. Mazumdar, \& K. Bhansali, Narratives from Women's Studies Family: Recreating Knowledge (pp. 83-84). New Delhi: Sage Publications.

Massey, D. (2001). Space, Place and Gender (pp. 175-186). UK \& USA: Polity Press.

Nath, H. and Kumar, S. (2017). India's Look/Act East Policy and the Northeast Region: A Critical Perspective. Space and Culture, India, 5(2), 7-20. https://doi.org/10.20896/saci.v5i2.265

Orlikowski, W. J. \&Baroudi J. J. (1991).Studying information technology in organizations: Research approaches and assumptions. Information Systems Research, 2(1).

Orr, C. M. (2012). Rethinking Women's and Gender Studies. NY: Routledge.

Patel, D. V., \& Khajuria, R. (2016). Political Feminism in India: An Analysis of Actors, Debates and Strategies. Friedrich Ebert Stiftung, 5-9.

Pateman, C. (2006). Citizenship and Equality: The Private/Public Divide. In I. Grewal and C. Kaplan (eds.) $2^{\text {nd }}$ Edition, An Introduction to Women's Studies: Gender in aTransnational World (pp. 155-159). New York: McGraw-Hill.

Raghavan, V. R. (2013). Consequences of Longterm Conflicts in Northeast India. Chennai: Vij Books India Pvt Ltd.

Richardson, V. R. (1997). Introducing Women's Studies: Feminist Theory and Practice, 
Second Edition. Washington Square: New York Univesity Press.

Roy, S. (2015). The Indian Women's Movement Within and Beyond NGOisation. Sage Journals, 96-114.

Rose, G. (2007). Feminism and Geography: The Limits of Geographical Knowledge, Cambridge, UK: Polity Press

Sachdeva, G. (2006). Demystifying Northeast. Dialogue, 2.

Sharma, D. A. (2014).Building Women's Studies in the Northeast. XIV National Conference on Women's Studies, Equality, Pluralism and the State: Perspectives From The Women's Movement (pp. 8-10). Guwahati: IAWS, CWDS.

Singh, Y. K. (2006). Fundamental of Research Methodology \& Statistics. New Delhi: New Age International $(P)$ Ltd.

Sreerekha, M. S. (2016). Whatever Happened to Women's Studies. Economic Political Weekly, 1-5.
(1949). University Education Commission, Radhakrishnan Commission.

Verghese, B. G. (2013). India's Northeast Resurgent: Ethnicity, Insurgency, Governance, Development, Delhi, India: Konark Publishers Pvt. Ltd

Robbins, W.,Luxton, M., Eichler, M. and Descarries, F. (2008). Minds of Our Own, Inventing Feminist Scholarship and Women's Studies in Canada and Quebec1966-76. Canada: Wilfrid Laurier University Press.

Wiegman, R. (2001). Statement: Women's Studies: Interdisciplinary Imperatives, Again. JStor, 514-518.

WSRC, G. U. (1997-2016). Activity Report. Guwahati: WSRC, GU.

Zimmerman, B. (2002). Women's Studies On Its Own, A Next Wave Reader in Institutional Change Edited by Robyn Wiegman. Durham, London: Duke University. 